\title{
Respon Penurunan Kadar Glukosa Darah Tikus (Rattus norvegicus) Hiperglikemik Setelah Pemberian Berbagai Minyak Konsumsi
}

\section{Response Decreased Blood Glucose Levels Of Hyperglycemic Rats (Rattus norvegicus) After Fedding of Various Edible Oils}

\author{
Enny Yusuf Wachidah Yuniwarti*, Tyas Rini Saraswati, Endang Kusdiyantini \\ Departemen Biologi, Fakultas Sains dan Matematika, Universitas Diponegoro \\ Jl. Prof. Soedarto, SH, Tembalang, Semarang \\ *Email: enny_yusuf@yahoo.co.id
}

Diterima 30 Juli 2018 / Disetujui 29 September 2018

\begin{abstract}
ABSTRAK
Olive oil, VCO, dan minyak buah merah memiliki manfaat sebagai antidiabetik karena ketiga minyak tersebut mengandung antioksidan yang tinggi. Penelitian ini bertujuan untuk membandingkan respon ketiga minyak tersebut terhadap persentase penurunan kadar glukosa darah, berat badan dan diameter sel hepatosit tikus jantan (Rattus norvegicus) hiperglikemik. Lima belas ekor tikus putih (Rattus norvegicus) jantan dengan umur sekitar 2 bulan digunakan sebagai hewan uji. Induksi aloksan sebesar $150 \mathrm{mg}$ per $\mathrm{kg}$ BB tikus secara intraperitonial dilakukan untuk mendapatkan tikus hiperglikemik. Design penelitian menggunakan Rancangan Acak Lengkap, dengan tiga perlakuan dan lima ulangan, yaitu P1 merupakan perlakuan dengan VCO 0,2 ml per BB tikus, P2 merupakan perlakuan dengan olive oil 0,2 ml per BB serta P3 merupakan perlakuan dengan minyak buah merah sebanyak $0,2 \mathrm{ml}$ per BB tikus per hari. Perlakuan diberikan secara oral selama empat minggu, data yang didapat dianalisa dengan ANOVA dan uji lanjut dengan uji LSD. Hasil yang didapat menunjukkan bahwa rerata persentase penurunan kadar glukosa darah dan bobot badan pada P1 berbeda nyata dengan P2 dan P3 ( $\mathrm{p}<0.05)$, sedang diameter sel hepatosit tidak menunjukkan perbedaan yang nyata antar perlakuan ( $p>0.05$ ), sehingga dapat disimpulkan bahwa VCO lebih potensial sebagai antidiabetik dibanding olive oil dan minyak buah merah,
\end{abstract}

Kata kunci: minyak konsumsi, antidiabetik, Rattus norvegicus

\section{ABSTRACT}

Some edible oils such as VCO, olive oil and red fruit oils have been found to have antidiabetic benefits because they contain high antioxidants. This study aims to compare the response of these three oils to the percentage decrease blood glucose levels, body weight and hepatocyte cell diameter of male rats (Rattus norvegicus) hyperglycemic. Fifteen rats (Rattus norvegicus) males with a age of about 2 months were used as test animals. Alloxan induction of $150 \mathrm{mg}$ per $\mathrm{kg}$ of rat BB was intraperitonially performed to obtain hyperglycemic rats. The research design was Randomized Complete Design, with three treatments and five replications, P1 was treated with $0.2 \mathrm{ml}$ VCO per rat BB, P2 was treated with olive oil $0.2 \mathrm{ml}$ per BB and P3 was treated with red fruit oil of $0,2 \mathrm{ml}$ per rat $\mathrm{BB}$ per day. The treatment was administered orally for four weeks, the data obtained were analyzed by ANOVA and further test by LSD test. The results showed that the mean percentage of decreased blood glucose and body weight on P1 was significantly different with P2 and P3 ( $p<0.05$ ), while hepatocyte cell diameter did not show significant difference between treatments ( $p>0.05)$, so it can be concluded that VCO more potential as antidiabetic than olive oil and red fruit oil.

Keywords: edible oil, antidiabetic, Rattus norvegicus

\section{PENDAHULUAN}

Beberapa penelitian telah menunjukkan adanya efek antidiabetik dari berbagai minyak konsumsi antara lain, olive oil, dan virgin coconut oil (Berraaouan et al., 2013). Virgin coconut oil (VCO) mengandung berbagai asam lemak rantai sedang yang telah terbukti mampu meningkatkan 
aktivitas fagositosis makrofag dan bersifat sebagai anti virus (Yuniwarti et al., 2013), terbukti mampu meningkatkan limfosit T-CD4 (Yuniwarti et al., 2012), dan juga mengandung antioksidan ( Nevin dan Rajamohan, 2006). Olive oil diduga berperan sebagai antioksidan (Owen et al., 2000). Minyak pandan merah mengandung carotenoid 12.000 ppm, $\beta$-carotene 700 ppm, tocopherol 11.000 ppm, oleic acid $74.6 \%$, linoleic acid $8 \%$, linolenic acid $8.36 \%$ yang berperan sebagai antioksidan sehingga melindungi sel dari radikal bebas yang dihasilkan tubuh (Kio et al., 2018),

Tubuh manusia mempunyai antioksidan yang mencegah kerusakan pada tubuh akibat adanya radikal bebas. Komponen antioksidan juga terdapat pada makanan yang mampu menangkap radikal bebas sehingga antioksidan berperan penting sebagai faktor yang mencegah terjadinya penyakit terutama penyakit degeneratif. Proteksi terhadap radikal bebas dapat ditingkatkan melalui pemberian makanan yang mengandung antioksidan. Beberapa penelitian menunjukkan bahwa makanan yang mengandung antioksidan terutama nutrien antioksidan mampu mencegah terjadinya penyakit (Alam et al., 2012).

Diabetes melitus merupakan salah satu penyakit degeneratif yang dipicu oleh adanya gangguan metabolisme karbohidrat, lemak dan protein. Gangguan metabolisme tersebut dihubungkan dengan terjadinya defisiensi hormon insulin atau berkurangnya aksi hormon insulin (Hozayen et al., 2012). Hormon insulin disekresi oleh sel beta-insula langerhasi pankreas. Kerusakan sel beta dapat menyebabkan defisiensi hormon insulin (Quesada et al., 2006). Penelitian ini betujuan untuk membandingkan persentase penurunan kadar glukosa darah tikus hiperglikemik setelah pemberian VCO, olive oil, dan minyak buah merah.

\section{METODE PENELITIAN}

Hewan uji yang digunakan dalam penelitian ini adalah tikus jantan dewasa sebanyak 15 ekor, berumur 2 bulan. Aklimasi dilakukan selama 7 hari dalam kondisi laboratorium dengan kepadatan 1 ekor per kandang, serta pakan dan air minum diberikan secara ad libitum. Selama masa aklimasi diamati tingkah laku makan dan minum, sehingga hewan yang sakit tidak digunakan dalam penelitian. Tikus hiperglikemik didapatkan melalui injeksi aloksan sebesar $150 \mathrm{mg} / \mathrm{kg}$ BB secara intraperitonial (Szkudelski, 2001). Selama tiga hari berturut turut dilakukan pemeriksaan kadar glukosa darah untuk memastikan aloksan sudah berfungsi dan kadar glukosanya stabil. Kadar glukosa darah awal dihitung saat pemeriksaan pada hari keempat setelah injeksi aloksan. Persentase penurunan kadar glukosa darah dihitung dari nilai penurunan dibagi nilai sebelum penurunan dikalikan $100 \%$. Perlakuan dilakukan selama 4 minggu, dan data yang didapat dianalisis dengan analisis of varians (ANOVA) menggunakan rancangan acak lengkap dengan tiga perlakuan yaitu, P1 merupakan kelompok perlakuan yang diberi VCO $0,2 \mathrm{ml} / \mathrm{BB} / \mathrm{hari}, \mathrm{P} 2$ merupakan kelompok perlakuan yang diberi olive oil 0,2 $\mathrm{ml} / \mathrm{BB} / \mathrm{hari}$ dan $\mathrm{P} 3$ kelompok perlakuan yang diberi Olive oil $0,2 \mathrm{ml} / \mathrm{BB} / \mathrm{hari}$. Berat badan ditimbang pada akhir perlakuan, sedangkan diameter sel hepatosit didapat dari pengukuran preparat hepar yang dibuat dengan metode parafin dan pewarnaan hematoxylin-eosin.

\section{HASIL DAN PEMBAHASAN}

Hasil Analysis Of Varians (ANOVA) dan uji lanjut LSD pada penelitian mengenai efek VCO, Olive oil dan minyak buah merah terhadap persentase penurunan kadar glukosa darah, bobot badan dan diameter sel hepatosit ditunjukkan pada Tabel 1. Rerata persentase penurunan kadar glukosa darah tikus hiperglikemik menunjukkan perbedaan yang signifikan antara perlakuan VCO dengan olive oil dan minyak buah merah $(\mathrm{P}<0.05)$, sedangkan antara perlakuan olive oil dengan minyak buah merah menunjukkan perbedaan yang tidak signifikan $(\mathrm{P}>0.05)$.

Penurunan persentase kadar glukosa darah terbesar pada perlakuan dengan VCO dibanding olive oil dan minyak buah merah. Hal tersebut diduga karena kondisi hiperglikemik akibat induksi aloksan akan meningkatkan reactive oxygen species, sehingga diperlukan antioksidan untuk menghambat kerusakan sel beta pankreas lebih lanjut. Pada proses penghambatan tersebut 
diperlukan energi lebih banyak dibanding saat kondisi normal, sehingga meskipun olive oil dan minyak buah merah juga mengandung antioksidan yang banyak, tetapi kedua minyak tersebut tidak mampu menyediakan energi yang lebih banyak sebagaimana halnya VCO. Asam laurat, merupakan komponen terbesar VCO, yang merupakan asam lemak rantai sedang sehingga dapat diabsorpsi langsung kedalam sel untuk secara cepat diubah menjadi energy dan resirkulasi asam laurat kedalam hepar akan melepaskan tambahan energi (Enig, 2004). Asam laurat juga diketahui meningkatkan insulin pada percobaan in vitro (Siddalingaswamy et al., 2011). Sistem pertahanan tubuh juga mampu dipertahankan dengan pemberian VCO (Iranloye et al., 2013).

Tabel 1. Rerata penurunan persentase kadar glukosa darah, bobot badan dan diameter sel hepatosit tikus putih hiperglikemik setelah perlakuan

\begin{tabular}{llll}
\hline & \multicolumn{1}{c}{ P1 } & \multicolumn{1}{c}{ P2 } & \multicolumn{1}{c}{ P3 } \\
\hline Penurunan Kadar Glukosa Darah $(\%)$ & $67,9^{\mathrm{a}} \pm 5,5$ & $54,52^{\mathrm{b}} \pm 4,7$ & $56,15^{\mathrm{b}} \pm 5,6$ \\
Bobot Badan $(\mathrm{g})$ & $218,6^{\mathrm{a}} \pm 23,2$ & $192,0^{\mathrm{b}} \pm 15,1$ & $188,0^{\mathrm{b}} \pm 12,3$ \\
Diameter sel hepatosit $(\mu \mathrm{m})$ & $15,15^{\mathrm{a}} \pm 2,3$ & $15,40^{\mathrm{a}} \pm 2,0$ & $16,05^{\mathrm{a}} \pm 1,3$ \\
\hline
\end{tabular}

Keterangan: P1 kelompok perlakuan VCO, P2 kelompok perlakuan olive oil, P3 kelompok perlakuan minyak buah merah. Rerata yang diikuti superskrip yang berbda pada baris yang sama menunjukkan perbedaan yang signifikan dengan uji ANOVA pada taraf kepecayaan 95\%.

Bobot badan tikus hiperglikemik terbesar terdapat pada perlakuan VCO dibanding perlakuan olive oil dan minyak buah merah. Kondisi tersebut terkait dengan penurunan kadar glukosa yang paling tinggi pada perlakuan VCO, sehingga cepatnya penurunan kadar glukosa darah akan mempercepat normalitas metabolisme glukosa. Peningkatan kadar gula darah atau kondisi hiperglikemik dapat terjadi karena penurunan sekresi hormon insulin atau penurunan respon sel terhadap hormon insulin (Hozayen et al., 2012). Hormon insulin disekresi oleh sel beta insula langerhansi pankreas. Sintesa hormon insulin terjadi dalam retikulum endoplasmik kasar yang berupa pro-hormon insulin, selanjutnya pro-insulin ditransfer ke apparatus golgi untuk pematangan dan pembelahan. Hasil pematangan dan pembelahan tersebut disimpan dalam granulagranula sel beta insula langerhansi pankreas untuk disekresi setelah adanya sinyal untuk sekresi hormon insulin (Fu et al., 2013). Semua proses tersebut memerlukan energi yang tersedia lebih banyak pada perlakuan VCO sehingga berat badan pada perlakuan VCO tidak mengalami penurunan.

Diameter sel hepatosit tikus hiperglikemik tidak menunjukkan perbedaan yang nyata pada semua perlakuan, baik VCO, Olive oil maupun minyak buah merah. Kondisi tersebut menunjukkan bahwa pemberian aloksan untuk induksi hiperglikemik tidak mengganggu struktur hepar. Hepar mengandung intra hepatic stem cells yang merupakan prekusor terjadinya replikasi selsel hepatosit. Replikasi sel hepatosit ini akan sangat membantu regenerasi sel sehingga pertumbuhan dan perkembangan hepar yang mengalami gangguan dengan cepat dapat diatasi (Fausto and Campbell, 2003). Antioksidan yang terkandung padaVCO, olive oil dan minyak buah merah, akan menjadi lebih stabil dengan adanya asam lemak jenuh (Yuniwarti dan Djaelani, 2016), sehingga diameter sel hepatosit pada hepar tikus hiperglikemik tidak berbeda pada semua perlakuan.

\section{KESIMPULAN}

Berdasar hasil yang diperoleh dalam penelitian ini dapat disimpulkan bahwa VCO menurunkan kadar glukosa darah tikus hiperglikemik lebih banyak dibanding olive oil dan minyak buah merah.

\section{UCAPAN TERIMAKASIH}

Terimakasih kepada UNDIP atas dana RPP tahun 2017 Nomor: 275-066/UN7.5.1/PG/2017 sehingga penelitian ini dapat dilaksanakan. 


\section{DAFTAR PUSTAKA}

Alam N., Nusrat Jahan Bristi, Rafiquzzaman. 2012. Review on in vivo and in vitro methods evaluation of antioxidant activity. SPJ. www.ksu.edu.sa

Berraaouan A, Abid S., and Bnouham M. 2013. Antidiabetic Oils. JDM 9 (6):499-505.

Enig M, 2004. The Importance of Saturated Fats for Biological Functions. http://www.westonaprice.org/abcs-ofnutrition/health-topics

Fausto N. and J. S. Campbell. 2003. The Role Of Hepatocytes and Oval Cells In Liver Regeneration and Repopulation. MOD 120 (2003) 117-130

Fu Z., E.R. Gilbert, and D. Liu. 2013. Regulation of Insulin Synthesis and Secretion and Pancreatic Beta-Cell Dysfunction in Diabetes. Current Diabetes Review 9 (1): 25-53

Hozayen W.G, Shaimaa S. Mahmoud, Kamal A. Amin and Rasha R. Ahmed. 2012. Modulatory Effects of Grape Seed Extract on Brain Neurotransmitters and Oxidative Stress in Alloxan Diabetic Rats. Jofamericanscience 2012;8(12) http://www.jofamericanscience.org.

Iranloye B., G. Oludare, M. Olubiyi. 2013. Antidiabetic and antioxidant effects of virgin coconut oil in alloxan induced diabetic male Sprague Dawley rats. JDM Vol.3, No.4, 221-22

http://dx.doi.org/10.4236/jdm.2013.34034

Kio A.D., T.R. Saraswati, and E.Y.W. Yuniwarti. 2018. The Effect of Red Fruit Oil (Pandanus conoideus) to the Histophysiology of Rat (Rattus norvegicus) Liver Exposed to Cigarette Smoke. Biosaintifika 10 (1) (2018) 125-130

Nevin K.G., T. Rajamohan. 2006, Virgin Coconut Oil Supplemented Diet Increases the Antioxidant Status in Rat Foodchem
J.Volume 99, Issue 2, 2006, Pages 260-266 doi:10.1016/j.foodchem.2005.06.056

Owen R.W , Attilio Giacosa,William E Hull, Roswitha Haubner, Gerd Würtele, Bertold Spiegelhalder, Helmut Bartsch. 2000. OliveOil Consumption And Health: The Possible Role Of Antioxidants. The Lan.Onco.J. Volume 1, Issue 2, October 2000, Pages $107-112$

Quesada I., Todorova, G Mariana; A-M Paloma, B Marta, E.M. Carneiro, F. Martin. A. Nadal and B. Soria. Glucose Induces Opposite Intracellular $\mathrm{Ca}{ }^{2+} \quad$ Concentration Oscillatory Patterns in Identified [alpha]and [beta]-Cells Within Intact Human Islets of Langerhans. Diabet.J, vol 55, september 2006: 2463-9.

Szkudelski T. 2001. The Mechanism of Alloxan and Streptozotosin Action in B Cell of Rat Pancreas. Physiol.Res. Vol 50:536-546. http://www.ncbi.nlm./ gov.pubmed.11829314.

Siddalingaswamy M., A. Rayaorth, and F. Khanum. 2011. Anti-diabetic effects of cold and hot extracted virgin coconut oil. JDM Vol.1, No.4, 118-123 (2011) doi:10.4236/jdm.2011.14016 http://www.scirp.org/journal/JDM/

Yuniwarti E.Y.W, W. Asmara, W.T. Artama, C.R. Tabbu, 2012a. The Effect of Virgin Coconut Oil on Lymphocyte and CD4 in Chicken Vaccinated Against Avian Influenza Virus. JITAA Vol 37 No1, March 2012

Yuniwarti E.Y.W, W. Asmara, W.T. Artama, C.R. Tabbu, 2013. Virgin Coconut Oil Meningkatkan Aktivitas Fagositosis Makrofag Pascavaksinasi Flu Burung. Jur.Vet Vol 14 No 2 Juni 2013.

Yuniwarti E.Y.W., and M. A. Djaelani. 2016. Mikroanatomi Hepar Tikus Putih Setelah Pemberian Berbagai Kadar VCO dan Olive Oil. Buletin Anfis. Volume 24, Nomor 1, Pp 21-26. 